\author{
Abstracta Iranica \\ Abstracta Iranica Revue bibliographique pour le domaine irano-aryen \\ Volume 32-33 | 2013 \\ Comptes rendus des publications de 2009-2010
}

\title{
Catherine Defernez. Les vases Bès à l'époque perse (Égypte-Levant). Essai de classification
}

\section{Astrid Nunn}

\section{OpenEdition}

1 Journals

\section{Édition électronique}

URL : http://journals.openedition.org/abstractairanica/40238

DOI : 10.4000/abstractairanica.40238

ISSN : 1961-960X

Éditeur :

CNRS (UMR 7528 Mondes iraniens et indiens), Éditions de l'IFRI

\section{Édition imprimée}

Date de publication : 1 décembre 2013

ISSN : 0240-8910

\section{Référence électronique}

Astrid Nunn, «Catherine Defernez. Les vases Bès à l'époque perse (Égypte-Levant). Essai de classification », Abstracta Iranica [En ligne], Volume 32-33 | 2013, document 52, mis en ligne le 01 juillet 2016,

consulté le 26 septembre 2020. URL : http://journals.openedition.org/abstractairanica/40238 ; DOI : https://doi.org/10.4000/abstractairanica.40238

Ce document a été généré automatiquement le 26 septembre 2020.

Tous droits réservés 


\title{
Catherine Defernez. Les vases Bès à l'époque perse (Égypte-Levant). Essai de classification
}

\author{
Astrid Nunn
}

\section{RÉFÉRENCE}

Catherine Defernez. « Les vases Bès à l'époque perse (Égypte-Levant). Essai de classification ", in : Pierre Briant, Michel Chauveau, éds., Organisation des pouvoirs et contacts culturels dans les pays de l'empire achéménide. Paris, De Boccard, 2009, p. 153-215. (Persika 14)

1 Bès est une divinité protectrice et apotropaïque importante du $\mathrm{I}^{\mathrm{er}}$ mill. et est représenté sur de nombreux objets. L'A. traite ici les vases en terre cuite. Le catalogue ne comporte de fait que les 92 vases récemment découverts sur le site de Tell el-Herr, site fortifié achéménide du Sinaï septentrional, ainsi que ceux de quelques autres sites du Delta oriental. La stratigraphie exacte du Tell el-Herr permet de bien dater les vases entre 475 et 425 et d'affiner la typologie des formes (Types A-L pour 7 phases). Ces vases étaient-ils liés à des pratiques magiques ? Y avait-il un lien entre le contenu et une certaine forme? Bès semble avoir joui de la faveur du Grand roi et des élites. Même si cette recherche intéressante est élargie en collationnant des vases du Levant (Tell elHesi, Tell Dor, Tell Mevorakh, Tell Jemmeh etc), il s'agit en réalité d'une étude du matériel de Tell el-Herr seulement. 


\section{AUTEURS}

\section{ASTRID NUNN}

Université de Munich 